\title{
Prevalence and harmfulness of winter wheat brown leaf rust (Puccinia recondita Rob. ex desm. f. sp. tritici) in the Southern Steppe of Ukraine
}

\author{
O. Markovska ${ }^{1 *}$, V. Dudchenko ${ }^{2}$, T. Grechishkina ${ }^{1}$, I. Stetsenko ${ }^{1}$ \\ ${ }^{1}$ Kherson State Agrarian and Economic University, 23 Stritenska St, 73006, Kherson, Ukraine \\ ${ }^{2}$ Institute of Rice of NAAS, Studentska Street 11, Antonivka, Skadovsk district Kherson region, 75705, \\ Ukraine \\ Corresponding author E-mail: mark.elena@ukr.net
}

Received: 05.12.2020. Accepted: 31.12.2020

\begin{abstract}
Apart from making farmers adapt agricultural technologies to new, more arid conditions in order to obtain sustainable and high yields, global climate change is also known to alter the pathogenicity of plant pathogens, the biological cycle of which is tightly associated with environmental factors. One of the most common diseases of winter wheat is brown leaf rust, caused by Puccinia recondita Rob. ex Desm. f. sp. tritici. In terms of its harmfulness and prevalence among other leaf and stem diseases, brown leaf rust is comparable to yellow and stem rust, septoria leaf blotch and other leaves blotches. Under arid conditions of the Southern Steppe of Ukraine, the disease manifests itself once every five years provided that sufficient moisture, indicated by the hydrothermal index above 1.0, is present during the spring and summer vegetation periods. The main factor influencing the intensity of pathogen development is moisture supply from April to June ( $\Sigma T P>50 \mathrm{~mm})$. In 2019, the amount of precipitation during this period was $194 \mathrm{~mm}$, which led to the disease development at the level of $18.4 \%$ with a spread of $27.2 \%$. Productivity of winter wheat varieties such as Antonivka, Blago and Maria was reduced by $10.8-11.3 \%$, when infected in the phase of milk grain stage (stages 73-77 on the $\mathrm{BBCH}$ scale), while net photosynthesis productivity decreased by $14.2-14.3 \%$, which translates to lower average yields of 2.3-3.1 t/ha. To maximize the productive potential of varieties and effectively control the development of the causative agent of brown leaf rust in winter wheat under favourable conditions for epiphytic development, the application of systemic fungicides with long-term protective effect imparted by the chemical group of triazoles (Colossal e.c., $1.0 \mathrm{l} / \mathrm{ha}$ ) is recommended in stages $69-71$ on the $\mathrm{BBCH}$ scale. This provides not only reliable crop protection (Eff.: $77.9-82.0 \%$ ), but also yields at the level of $3.3-4.6 \mathrm{t} / \mathrm{ha}$, depending on the variety under non-irrigated conditions.
\end{abstract}

Keywords: Diseases; Pathogen; Protection; Leaves; Moisture; Yield

\section{Introduction}

In recent years, the achievement of high and stable yields of cereal crops in Ukraine and globally is increasingly hampered by a number of factors, particularly agroclimatic and biotic. Agroclimatic factors can both increase agricultural production and affect the risk of damage by pests and pathogens (Melnik \& Chayka, 2002).

One of the modern environmental issues, related to agroclimatic factors, is climate change on the planetary scale (Pisarenko et al., 2019). For the zone of the Southern Steppe of Ukraine, this has primarily led to an increase in winter temperatures by $1.9-2.0^{\circ} \mathrm{C}$ and in summer temperatures - by $1.5-1.6^{\circ} \mathrm{C}$, which caused an increase in the sum of effective temperatures above $5^{\circ} \mathrm{C}$ by $673{ }^{\circ} \mathrm{C}$. The amount of precipitation also changed drastically. In recent years, this parameter has increased by $111 \mathrm{~mm}$, or $33 \%$, and is now nearly $450 \mathrm{~mm}$. However, distribution of precipitation over the growing season is not uniform and during dry summer months, it exhibits a shower-like character (Vojegova, 2019). Such increase in precipitation can create favourable conditions for more active development of phytopathogenic microorganisms, which can significantly worsen the quality of grain yield and reduce its size.

All abovementioned factors force farmers in the south to adapt technologies for growing crops to both water scarcity and excessive moisture during certain vegetation periods. Application of mineral fertilizers and organo-mineral complexes with various pesticides is rationally combined, which not only allows increasing the productive potential of plants but also to reliably protects them from pathogen damage (Markovska et al., 2018; Markovska \& Grechyshkina, 2020).

Brown leaf rust, caused by the fungus Puccinia recondita (syn. P. triticina Eriks.), is the most prevalent of all rust diseases of wheat ( Triticum aestivum L.). It is common in most regions of the world and occurs more often than wheat stem rust ( $P$. graminis $\mathrm{f}$. Sp. Tritici) or yellow wheat rust ( $P$. striiformis f. Sp. Tritici) (Bolton et al. 2008, Peksa \& Bankina, 2019). Opinions are divided on the classification of the pathogen that causes brown rust of rye and wheat. Some scientists claim that both wheat and rye brown rust are caused by a single pathogen $-P$. recondita, identified by Cummins, while others state that different species cause brown rust in different crops: $P$. recondita - in rye and $P$. triticina - in wheat. Data is also available on the racial composition of wheat $P$. recondita. More than 70 races were identified in North America, 35 races - in Canada and more than 100 races - in Europe. Unfortunately, there is no information on the causative agents of rye brown rust. $P$. recondita is a heteroxenic fungus with a complex life cycle. For its development, the fungus relies on cereals as the main hosts and on various alternative plants as intermediate hosts, depending on the specialization of the pathogen (Peksa \& Bankina, 2019). Under Ukrainian conditions, the pathogen develops via a shortened (vegetative) cycle. The intermediate hosts are rhubarb plants ( Thalict rum spp.), which have no 
practical significance in the cycle of pathogen development but can be reservoirs of infection or promote the formation of new fungal races as a consequence of sexual reproduction (Dermenko et al., 2012). In the process of development, the pathogen mainly affects the leaves of winter wheat and less often - leaf sheaths and plant stems. Initially, chaotically arranged rusty-brown uredinia tend to appear on the upper side of the leaf blade. After 10-15 days, teliopustules, which are dark in color and contain teliospores of the fungus, are formed under the epidermis (Figure 1) (Dermenko et al., 2013).

a)
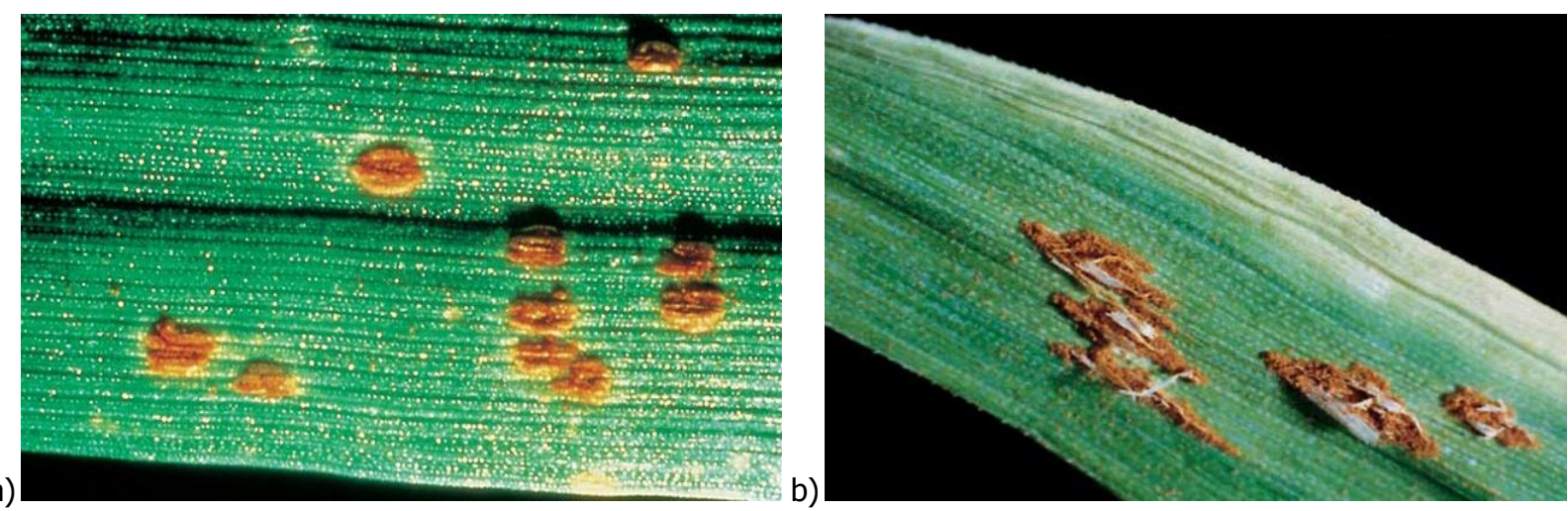

Figure 1. Uredinia (a) and teliopustules (b) P. recondita Rob. Ex Desm. f. sp. Tritici on the leaves of winter wheat [images: a) agroflora.ru(c)2013, b) cropsience.bayer.us.2018].

$P$. recondita is an obligate parasite capable of producing infectious urediniospores as long as the infected leaf tissue remains alive. Urediniospores, in turn, are dispersed by wind and infect host plants hundreds of kilometres away from their source, which can lead to epiphytoties of winter wheat brown rust at the continental level (Bolton et al., 2008). The degree of harmfulness of rust depends on the phase of plant development, scale and duration of damage, environmental factors and the robustness of the variety (Sukhomud \& Lyubich, 2011).

In the case of a severe damage to the plant, the entire leaf blade is covered with uredinia, whilst individual leaves are twisted and wilted. The pathogen overwinters with the help of the urediniomycelium, urediniospores of which are able to tolerate low winter temperatures. During the vegetation of winter wheat, the pathogen can form several generations, reaching the peak of infection in phases 61-77 on the BBCH scale (macrostages: flowering - formation of karyopsises). Under conditions of early damage to plants in autumn, the re-emergence of infection can be observed in phases 33-34 on the scale of $\mathrm{BBCH}$, with the spread of the disease reaching $20-22 \%$, and the development of $6-7 \%$. By phases $73-75$ on the $\mathrm{BBCH}$ scale, the disease can affect almost $100 \%$ of plants, with damage observed on $50-80 \%$ of the plants (Sarhang, 2006).

The harmfulness of the disease arises from the metabolic disruption in the affected plant, which entails decreased assimilation, changes in chlorophyll content, increased respiration as well as reduced intensity of transpiration, lower winter and drought resistance due to ruptures in the leaf epidermis. Excess rainfall leads to growth retardation, whereas the lack of moisture causes premature death of the affected leaves. Ultimately, these result in yield losses (Kovalishina, 2010).

The aim of the study was to determine the development features of the brown leaf rust causative agent, P. recondita Rob. Ex Desm. f. sp. tritici, on winter wheat under the conditions of the Southern Steppe of Ukraine and to investigate the impact of plant damage on the productivity of crop varieties when using different methods of plant protection.

\section{Materials and Methods}

Field and laboratory studies were conducted in 2017-2019 on the experimental field of the state enterprise (SE) "Kopani" of the Institute of Irrigated Agriculture National Academy of Agrarian Sciences AAS in Belozersky district of Kherson region (Ukraine).

The technology of growing crops, with the exception of the studied factors, was generally accepted for the conditions of the Southern Steppe of Ukraine. The previous crop for winter wheat was - black summer fallow. Sowing was carried out in the third tenday period of September. The soil of the experimental plots was dark chestnut in color, medium loamy, slightly saline on the carbonate loess. The average humus content in the $0-30 \mathrm{~cm}$ layer was $2.15 \%$, total nitrogen content $-0.18 \%$, phosphorus $-0.15 \%$ and potassium $-2.6 \%$.

The influence of biological and chemical methods of plant protection on the productivity of winter wheat varieties of Ukrainian selection, Antonivka, Maria and Blago, was studied. The former included the use of the biological product Trichoderma blend biogreenmicrozymetr, cs $(50 \mathrm{ml} / \mathrm{t})$ for the seed treatment before sowing. Biological product with an insecticidal-fungicidal mode of action, Guapsin, s (5.0 l/ha), was used for spraying the plants in the flag leaf phase (39-47 BBCH). The chemical method entailed the application of the fungicide seed treatment Orius Universal ES, e.s. $(2 \mathrm{l} / \mathrm{t})$ for the seed treatment before sowing and spraying of the plants in the phase of the flag leaf $(39-47 \mathrm{BBCH})$ with a fungicide, Kolosal, e.c. $(1,0 \mathrm{l} / \mathrm{ha})$. The norm of the solution for treatment of the seeds was $10 \mathrm{l} / \mathrm{t}$ and for spraying of the plants $-200 \mathrm{l} / \mathrm{ha}$.

Record taking and monitoring of the experiments were performed in accordance with the methods of S.O. Tribel and others. (Tribel et al., 2001; Koishibaev, 2018). To assess the degree of damage to wheat plants by brown rust the scale of L.F. Rusakova (Tribel et al., 2001) was used.

The hydrothermal index of Selyaninov (HTI) was determined by using the standard formula (Kuleshov, 2018). Net photosynthesis productivity was calculated using the formula of (Rudnyk-Ivashchenko \& Grigorashchenko, 2010): The total area of the experimental plot was $50 \mathrm{~m}^{2}$ and of the record area $-25 \mathrm{~m}^{2}$. Four experimental replicas were performed. Field, laboratory, mathematical and statistical methods were used in accordance with the generally accepted methods and guidelines in Ukraine (Yeshchenko et al., 2005; Ushkarenko et al., 2008; Dimov \& Bojarkina, 2019). 


\section{Results and Discussion}

The primary determinant of the emergence, spread and development of diseases is the presence of required levels of heat and moisture in certain phases of ontogenesis of pathogens and plants. The dynamics of weather conditions during the day, season and year largely determines the variability and diversity of the ecological state, in which plant pathogens develop (Kuleshov, 2018). In the south of Ukraine, the main limiting factor in the development of the pathogen $P$. recondita, according to the biological requirements (Kuleshov \& Bilyk, 2008), is moisture. Since most years in this zone are arid, with high average daily temperatures between April and June, the frequency of brown rust outbreaks in the Southern Steppe is once every five years (Derecha et al., 2018). Analysis of weather conditions during the study years shows that they differ in terms of moisture supply, which is confirmed by the amount of precipitation in the most critical period for the development of disease - September-October (autumn vegetation) and April-June (spring and summer vegetation). For instance, in 2017-2018 the amount of precipitation from April to July was similar to or smaller than the long-term average, while in 2019 , the amount of precipitation during this period was greater than the long-term average by $49 \%$, and in June - exceeded it by $81 \%$ (Figure 2 ).

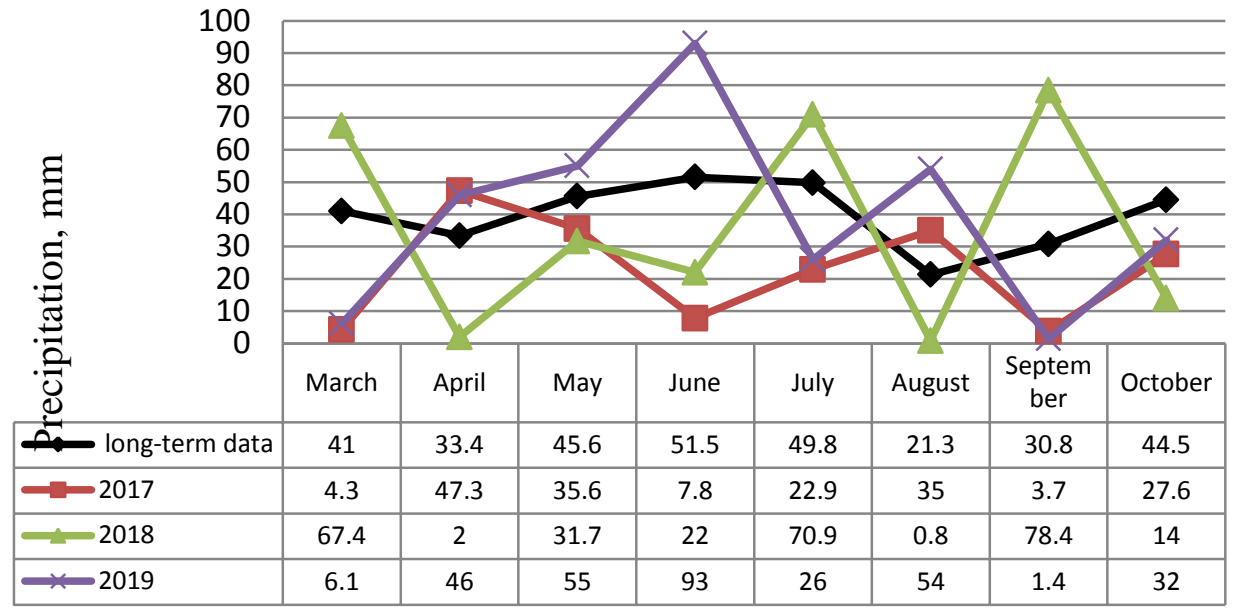

Figure 2. The amount of precipitation during the autumn and spring-summer vegetation periods of winter wheat (2017-2019).

The indicator of the amount of precipitation during the vegetation period is closely related to another parameter, the hydro-thermal index (HTI), which can be successfully used to predict the development of diseases, whose causative agents intensively develop following heavy rainfall at low air temperatures. The value of HTI is directly proportional to the amount of precipitation and inversely proportional to the air temperature (Kuleshov \& Bilyk, 2008).

This study has found that the increase in HTI to 1.1 on average (indicating the optimal level of moisture), from April to June inclusive in 2019 , contributed to the spread of brown rust from $8.5 \%$ in stages $30-32$ to $27.2 \%$ in stages $70-77$ on the $\mathrm{BBCH}$ scale, respectively. In 2017 and 2018 the average HTI for three months of spring and summer vegetation was 0.73 and 0.28 , correspondingly, implying a low level of moisture, which did not promote the development of the pathogen. Thus, in 2017, the spread of brown rust was $16.1 \%$ and in $2018-17.9 \%$. On average, for three years of research (2017-2019), the spread of the disease from April to June was 4.3\%, $13.7 \%$ and $20.4 \%$, respectively (Figure 3 ).
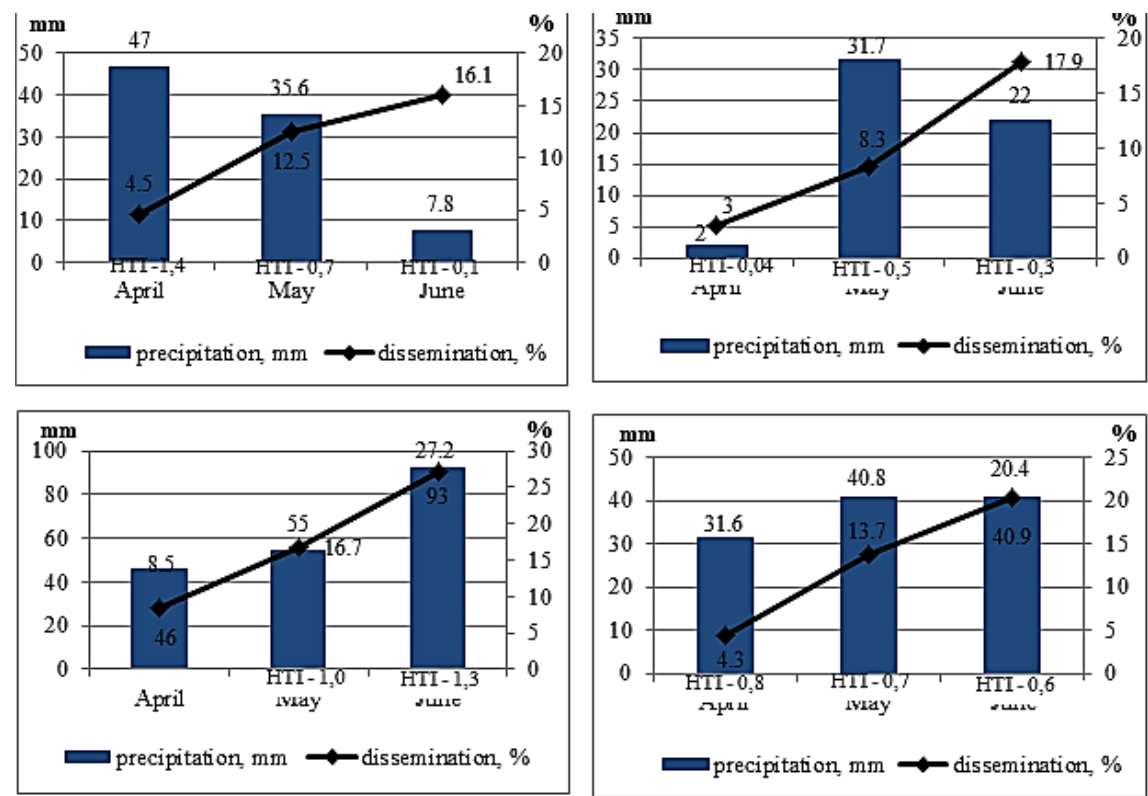

Figure 3. Spread of brown rust ( $P$. recondita Rob. ex Desm. F. Sp. Tritici) on winter wheat depending on the amount of precipitation in spring and summer. 
A.V. Kuleshov proposed a number of indicators that, based on the analysis of meteorological and climatic data, can be used to characterize the state of the pathological process for aerogenic, airborne and leaf-stem infections. Among them, the main and summative indicator is the index of favourable weather conditions for the pathogen development.

According to calculations, the weather conditions in 2017-2019 differed significantly, which was the main reason behind the differences in the dynamics of the brown rust development on winter wheat. Owing to low humidity in 2017 (HTI < 1.0) and drought in 2018 (HTI < 0.5) the index of favourable weather conditions was 103.6 and 34.6 units, respectively. These characterized the state of pathogen development as "weak" and "retarded", correspondingly (Table 1). Development of the disease in the control variants (without treatment) was $8.8 \%$ in 2017 and $6.0 \%$ in 2018. Given the optimal moisture in 2019 (HTI > 1.0), the index of favorable weather conditions was 284 units (Table 1), characterizing the pathogen development as "moderate ". This was generally reflected in the results of the monitoring in variants without protective measures, where the disease development was $18.4 \%$, which was 2.1 times greater than in 2017 and 3.1 times greater than in 2018 (Table 1).

Table 1. Comparative analysis of the development of wheat brown rust according to the predictors of weather conditions during the vegetation periods (2017-2019).

\begin{tabular}{lllll}
\hline Indicators & $\mathbf{2 0 1 7}$ & $\mathbf{2 0 1 8}$ & $\mathbf{2 0 1 9} \mathbf{~ p .}$ & $\begin{array}{l}\text { Average } \\
\mathbf{2 0 1 7 - 2 0 1 9}\end{array}$ \\
\hline Average amount of precipitation, P & 11.3 & 9.3 & 17.6 & 13.1 \\
Hydro-thermal index, HTI & 0.73 & 0.28 & 1.1 & 0.7 \\
C intensiveness, $C_{\text {int. }}$ & 1.13 & 0.93 & 1.76 & 1.31 \\
C multiplicity, $\mathrm{C}_{\mathrm{m}}$ & 0.09 & 0.07 & 0.12 & 0.4 \\
Index of favorable weather conditions, $\mathrm{I}_{\mathrm{f}}$ & 103.6 & 34.6 & 284.0 & 109.2 \\
Disease development \% & 8.8 & 6.0 & 18.4 & 11.1 \\
Character of the pathological process & Weak & Retardation & Moderate & Strong \\
& development & development & development \\
\hline
\end{tabular}

Reduction in the weight of the grain from the ear is one of the most economically damaging consequences of wheat brown rust. In epiphytic years, yield losses can range from $30 \%$ to $70 \%$ in susceptible varieties (Peksa \& Bankina, 2019). The main cause of such losses is a decrease in the assimilation surface area of the leaves - the photosynthetic organ and the part of the plant that is the most affected by brown rust. Various compounds produced during photosynthesis ensure development of plants with certain qualitative and quantitative features following seed formation.

Therefore, for a more complete assessment of the photosynthetic activity of winter wheat the indicator known as the net photosynthesis productivity (NPP) is used. NPP determines the amount of dry matter formed in the process of photosynthesis during the day per $1 \mathrm{~m}^{2}$ of leaves (Zhelyazkov et al., 2012). I.T. Netis reported that the increase in dry matter of the leaf surface of winter wheat per $1 \mathrm{~m}^{2}$ per day can range from $1.1 \mathrm{~g}$ to $9.8 \mathrm{~g}$ depending on the phase of plant development, the condition of its leaf surface and cultivation techniques (Netis, 2011).

Analysis of the effect of winter wheat leaf damage by the causative agent of brown rust ( $P$. recondita Rob. ex Desm. F. Sp. Tritici) shows a significant relationship between the degree of plant damage and NPP. For instance, with the development of the disease at the level of $2.0-2.5 \%$, the NPP was $6.9-7.09 \mathrm{~g} / \mathrm{m}^{2}$ per day. Increase in the degree of plant damage $(3.8-4.9 \%)$ led to the reduction in the NPP by $3.5-8.5 \%\left(6.84-6.31 \mathrm{~g} / \mathrm{m}^{2}\right.$ per day). The plant damage at the level of $10.8-11.3 \%$ reduced the NPP even further - by $14.2-14.3 \%\left(5.91-6.08 \mathrm{~g} / \mathrm{m}^{2}\right.$ per day) (Figure 4$)$.

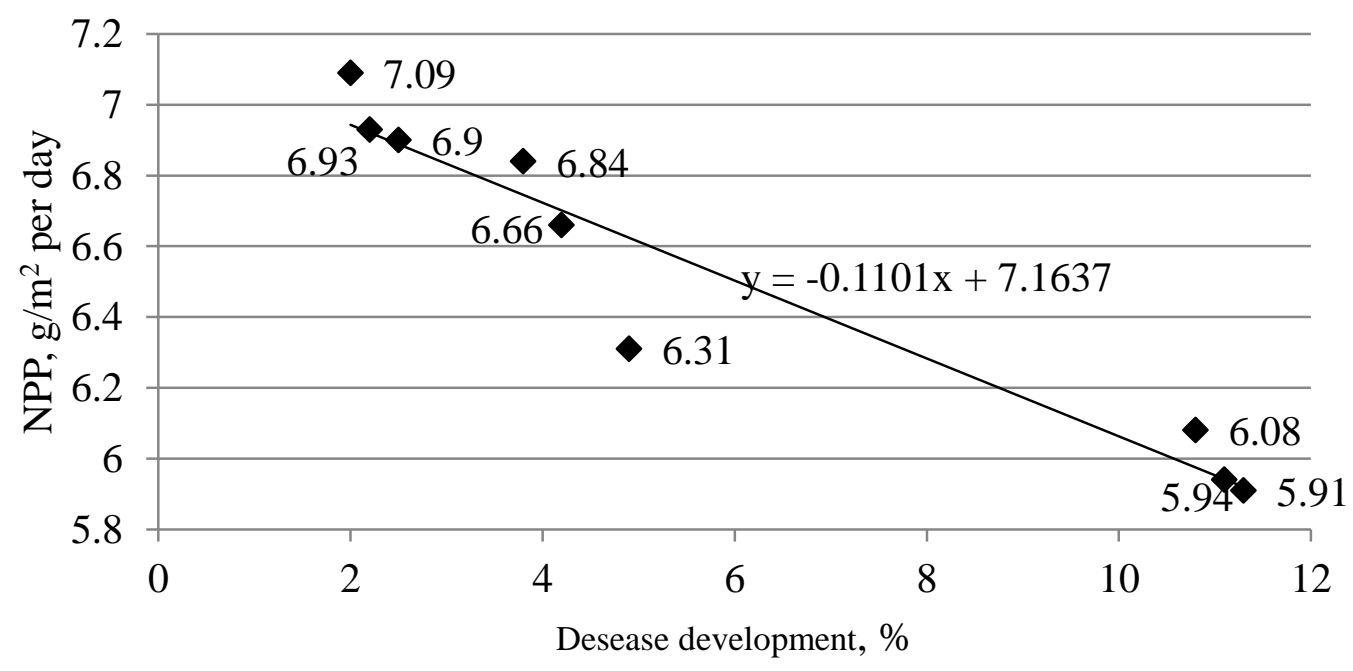

Figure 4. Dynamics of the net photosynthesis productivity depending on the degree of damage to the wheat leaf surface by brown rust ( $P$. recondita Rob. ex Desm. F. Sp. Tritici., 2017-2019).

Results of yield analysis of early-ripening varieties Antonivka, Blago and Maria and comparison of the impact of different plant protection methods on the development and spread of brown leaf rust on winter wheat, showed that the average yield in 20172019 in variants without protective measures for Antonivka variety was 2.3 t/ha, for Blago - $2.8 \mathrm{t} / \mathrm{ha}$ and for Maria - $3.3 \mathrm{t} / \mathrm{ha}$. The disease development ranged from $10.8 \%$ to $11.3 \%$ on average depending on the variety during the years of research. 
The spraying of plants in the phase of the flag leaf (39-47 BBCH) with a biological product Guapsin, s. (5.0 I/ha), a broad spectrum insecticide and fungicide that contains an aqueous suspension of bacterial strains of Pseudomonas aureofaciens $\mathrm{B}-306$ (1MB B 7096) and Pseudomonas aureofaciens B - 111 (1MB B - 7097) and products of their metabolism, contributed to the reduction of plant damage in Antonivka variety by $56.6 \%$, Blago - by $61.1 \%$ and Maria - by $65.8 \%$ on average in $2017-2019$. The yield of three aforementioned varieties was 2.8, 3.4 and 3.8 t/ha, respectively (Figure 5).

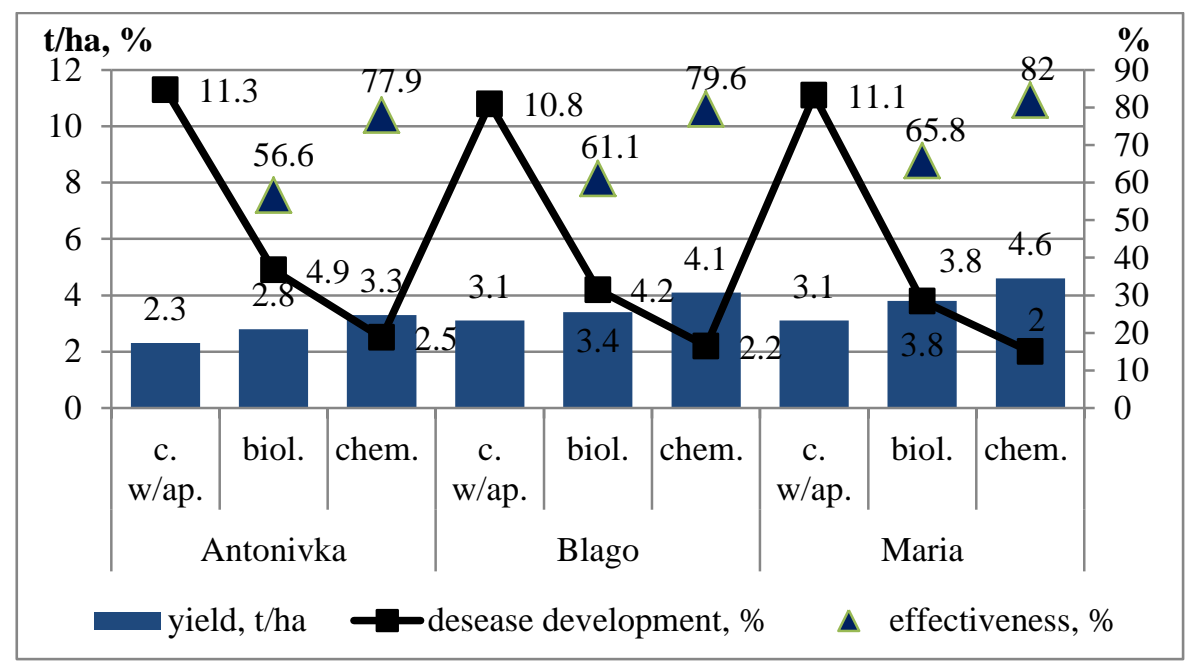

Figure 5. Yields of winter wheat varieties depending on development of brown rust (P. recondita Rob. ex Desm. F. Sp. Tritici, LSD 05 $0.16 \mathrm{t} / \mathrm{ha}, 2017-2019)$.

The spraying of plants in the phase of the flag leaf $(39-47 \mathrm{BBCH})$ with a systemic fungicide Colossal, e.c. norm $1.0 \mathrm{l} /$ ha, which inhibits the biosynthesis of ergosterol in the cell membranes of pathogens and disrupts major metabolic pathways, led to a significant reduction in the plant damage. For instance, the average disease development in 2017-2019 for the variety Antonivka was $3.3 \%$, for Blago $-2.2 \%$ and Maria $-2.0 \%$, which was smaller compared to controls without treatment by $3.4-5.6$ times depending on the variety. The effectiveness of fungicide for the variety Antonivka was $77.9 \%$, for Blago - 79.6\% and for Maria $82.0 \%$ (Figure 5).

\section{Conclusion}

Results of this study demonstrated that the development and spread of brown leaf rust (P. recondita Rob. Ex Desm. F. Sp. Tritici) on winter wheat under the arid conditions of the Southern Steppe of Ukraine, for crops cultivated without any irrigation, depends primarily on the amount of precipitation during the spring and summer vegetation periods. When precipitation was abundant, increased value of the index of favourable weather conditions could predict high degree of plant damage $\left(I_{f}-284\right)$. In dry years with low moisture $(\mathrm{HTI}<1.0)$, the spread and development of the disease were in the ranges of $16.1-17.9 \%$ and $6.0-8.8 \%$, respectively. Thus, the decision to take protective measures depends on the robustness of the variety and predictions of the rate of pathogen development in subsequent growth periods. Damage to the leaf apparatus of plants during the years with optimal moisture (HTI> 1.0) at the levels above $10 \%$ led to a decrease in net photosynthesis productivity by $14.2-14.3 \%$. Application of systemic fungicides (Colossal, $1.0 \mathrm{l} / \mathrm{ha}$ ) proved to be efficient (77.9-82.0\%) and allowed to preserve 1.0-1.5 t/ha of the yield in years with higher values of the index of favourable conditions.

\section{References}

Bolton, Melvin, D., Kolmer, James, A., Garvin, David, F. (2008). Wheat leaf rust caused by Puccinia triticina. Molecular Plant Pathology. 9 (5), 563-575.

Derecha, O., Hrytsiuk, N., Bakalova, A. (2018). The effectiveness of the combined use of fungicides and nitrogen fertilizers to protect winter wheat from diseases in the Northern Forest-Steppe Visnyk of Lviv National Agrarian University. Series: Agronomy, 22 (2), 112-118.

Dermenko, O.P, Panchenko, Y.S, Gavrilyuk, L.L. (2012). Dangerous disease of winter wheat. Brown leaf rust (Puccinia recondita Rob. Ex Desm. F. Sp.tritici): distribution and development in the Forest-Steppe of Ukraine. Quarantine and plant protection, 11, 4-7. Dermenko, O.P, Panchenko, Yu.S., Gavrilyuk, L.L. (2013). Protection of winter wheat from brown leaf rust. Quarantine and plant protection, 5, 9-11.

Dimov, O.M., Bojarkina, L.V. (2019). Method correlation and regression analysis as the tool of assessment of efficiency of technologies of cultivation of crops on the irrigated lands. Irrigated agriculture, 71, 44-52.

Koishibaev, M. (2018). Wheat Diseases Food and Agriculture Organization of the United Nations (FAO). Ankara.

Kovalishina, G.M. (2010). Selection of winter wheat at the Myronivka Institute of Wheat for disease resistance. Bulletin of the Ukrainian Society of Geneticists and Breeders, 8(2), 291-299.

Kuleshov, A.V., Bilyk, M.O. (2008). Phytosanitary monitoring and forecast. Kharkiv: Espada. (in Ukrainian).

Kuleshov, A.V. (2018). Forecast of crop diseases development next year on a biometeorological basis.

Markovska, O.Ye., Pikovskyi, M.Y., Nikishov, O.O. (2018). Optimization of the system of irrigated winter wheat protection against harmful organisms in southern Ukraine. Bioresources and nature management, 10 (3-4), 98-104.

Markovska, O.Y., Grechyshkina, T.A. (2020). Productivity of winter wheat varieties depending on elements of growing technology under the conditions of Southern Step of Ukraine. Agrobiology. 1, 96-103. 
Melnik, P.P., Chaika, V.M. (2002). Evaluation of economic efficiency of plant protection measures (on the example of winter wheat). Plant protection and quarantine, 48, 224-228.

Netis, I.T. (2011). Winter wheat in the south of Ukraine: monography. Kherson: Oldiplyus. (in Ukrainian).

Peksa, K., Bankina, B. (2019). Characterization of Puccinia recondita, the causal agent of brown rust. Agricultural sciences. Research for rural development, 2, 70-76.

Pisarenko, V.M., Pisarenko, P.V., Pisarenko, V.V. (2019). Directions of adaptation of the crop industry to regional climate change. Proceed. II Int. Sc. Conf. "Climate change and agriculture. Challenges for agricultural science and education". Kyiv.

Rudnyk-Ivashchenko, O.I., Grigorashchenko, L.V. (2010). Features of photosynthesis of millet plants sowing. Bulletin of Agrarian Science, July, 35-38.

Sarhang, E.G. (2006). Biological features, specialization and virulence polymorphism Puccinia recondita Rob. ex Desm. f. sp. tritici Erikss. the causative agent of brown leaf rust of wheat in the eastern part of the Forest-Steppe of Ukraine. (in Ukrainian).

Sukhomud, O.G., Lyubich, V.V. (2011). Formation of grain quality of winter wheat at different rates of fertilizers and the use of fungicide Falcon.460 EC, k.e. and its resistance to brown leaf rust. Agrobiology, 6, 114-119.

Tribel, S.O. (Ed). (2001). Methods of testing and application of pesticides. Kiev. (in Ukrainian).

Ushkarenko, V.O., Nikishenko, V.L., Goloborodko, S.P., Kokovihin, S.V. (2008). Disperse and correlation analysis in agriculture and plant science: textbook. Kherson: Aylant.

Vozhegova, R.A. (2019). Directions of adaptation of the crop industry to regional climate change. Proceed. II Int. Sc. Conf. "Climate change and agriculture. Challenges for agricultural science and education". Kyiv.

Yeshchenko, V.O., Kopytko, P.H., Kostohryz, P.V., Opryshko, V.P. (2014). Foundations of scientific investigations in agronomy: textbook. Vinnytsia: Edelveis i K. (in Ukrainian).

Zhelyazkov, O.I., Samoilenko, O.A., Pedash, O.O., Bondarenko, A.S., Boyko, O.V., Romanenko, O.L. (2012). Photosynthetic activity of winter wheat plants depending on the technological methods of cultivation in Prysyvashsha. Bulletin of the Institute of Steppe Zone Agriculture of NAAS of Ukraine, 2, 103-106.

\section{Citation:}

Markovska, O., Dudchenko, V., Grechishkina, T., Stetsenko, I. (2020). Prevalence and harmfulness of winter wheat brown leaf rust (Puccinia recondita Rob. ex desm. f. sp. tritici) in the Southern Steppe of Ukraine. Ukrainian Journal of Ecology, 1066), 69-74. 